\title{
The impact of entomopathogenic nematodes on a non-target, service-providing longhorn beetle is limited by targeted application when controlling forestry pest Hylobius abietis
}

\author{
Christopher D. Harvey*, Khalil M. Alameen, Christine T. Griffin \\ Department of Biology, National University of Ireland Maynooth, Co. Kildare, Ireland
}

\section{H I G H L I G H T S}

- Entomopathogenic nematodes (EPN) are used to control the large pine weevil.

- EPN can infect and reproduce in nontarget beetle Rhagium bifasciatum within deadwood.

- R. bifasciatum infection in EPN-treated deadwood was lower in field than in lab.

- EPN can locally persist in deadwood in the field by recycling in

R. bifasciatum.

- Overall impact on R. bifasciatum is limited by targeted EPN application.

\section{A R T I C L E I N F O}

\section{Article history:}

Received 10 October 2011

Accepted 18 April 2012

Available online 26 April 2012

\section{Keywords:}

Steinernema

Heterorhabditis

Entomopathogenic nematodes

Pine weevil

Cerambycid

Non-target risk assessment
G R A P H I C A L A B S T R A C T

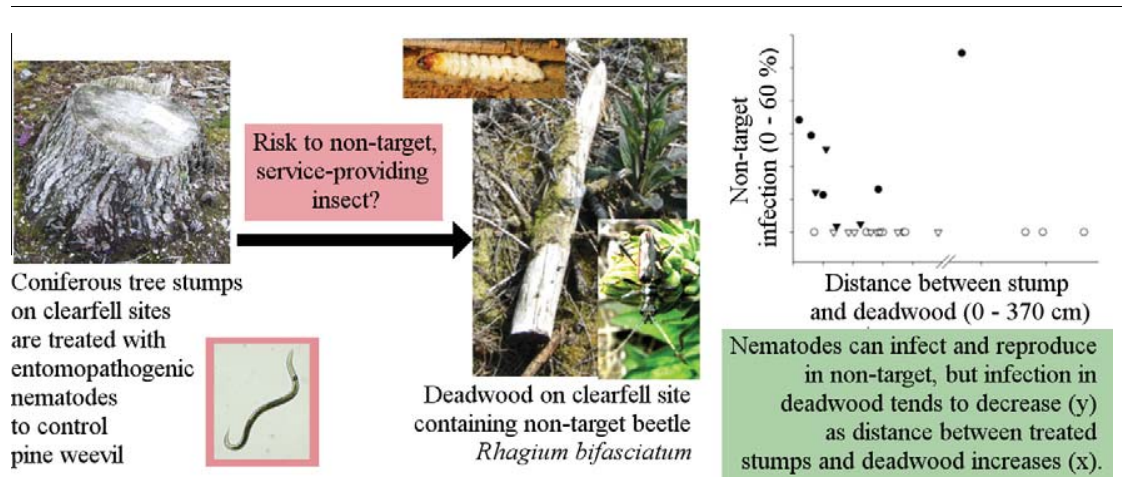

\section{A B S T R A C T}

Entomopathogenic nematodes are being applied to tree stumps on coniferous clearfell sites in Europe for inundative biological control of the large pine weevil (Hylobius abietis; Coleoptera: Curculionidae), a major forestry pest. We investigated the risk that two nematode species, Steinernema carpocapsae and Heterorhabditis downesi (Nematoda: Rhabditidae), present to longhorn beetle Rhagium bifasciatum (Coleoptera: Cerambycidae), a service-providing, non-target saproxylic insect on clearfell sites. In a Petri dish assay, larvae of $R$. bifasciatum were less susceptible $\left(\mathrm{LC}_{50} 24-42\right)$ than pupae or adults $\left(\mathrm{LC}_{50} \leqslant 10\right)$ to infective juveniles (IJs) of S. carpocapsae and $H$. downesi. S. carpocapsae and $H$. downesi reproduced within R. bifasciatum larvae, pupae and adults, with up to 130,000 IJs emerging per insect. When we applied 1.8 million IJs (half the number recommended per tree stump containing pine weevil) to deadwood logs in laboratory and field experiments, both nematode species infected more than $50 \%$ of $R$. bifasciatum within the logs. Field application at a lower, more realistic rate $(18,000$ IJs per log) resulted in $0-11 \%$ infection. The two nematode species caused similar rates of infection within logs and infected $R$. bifasciatum larvae more than $4 \mathrm{~cm}$ deep within the wood. On six clearfell sites sampled one to twelve months after $S$. carpocapsae had been inundatively applied to tree stumps for suppression of pine weevil, $<10 \%$ of deadwood logs contained infected $R$. bifasciatum and $<4 \%$ of 1989 R. bifasciatum individuals in logs were infected. Infection was recorded a year after nematodes had been applied, however, suggesting that nematodes were recycling within logs in the field. Incidence of $R$. bifasciatum infection decreased significantly with increasing distance between a $\log$ and the nearest treated tree stump. Thus, our results indicate that entomopathogenic nematodes can infect and recycle in $R$. bifasciatum, but that the risk to this and other saproxylic non-target insects is limited by the targeted application of nematodes to tree stumps.

(c) 2012 Elsevier Inc. All rights reserved.

\footnotetext{
* Corresponding author.

E-mail address: Christopher.D.Harvey@nuim.ie (C.D. Harvey).
} 


\section{Introduction}

The large pine weevil, Hylobius abietis Linnaeus (Coleoptera: Curculionidae), is one of the major forestry pests across Northern Europe (Leather et al., 1999). It has been estimated that failure to control this pest could result in damages of up to $€ 140$ million per annum (Långström and Day, 2004). The pest status of $H$. abietis is associated with replanting on recently felled clearfell sites where the larvae develop under the bark of coniferous tree stumps. The adults feed on the bark of planted conifer seedlings and can cause high mortality of seedlings if these are not protected (Leather et al., 1999). In an effort to reduce the use of chemical pesticides, entomopathogenic nematodes are currently being used as inundative biological control agents against the large pine weevil in the UK and Ireland (Evans et al., 2004; Anon, 2007) and trials have been conducted in Poland (Skrzecz and Majewski, 2010). Entomopathogenic nematodes (EPN; Nematoda: Rhabditidae) are pathogens that invade, kill and then reproduce within insects (Kaya and Gaugler, 1993). The free-living stage of EPN is the infective juvenile (IJ) that kills the host by releasing pathogenic bacteria with which it is mutually associated (Forst et al., 1997; Dowds and Peters, 2002). Due to their potentially wide host range, ease of production and safety to vertebrates, EPN have become popular inundative biocontrol agents that have been used successfully against insect pests in a variety of settings (Gaugler et al., 1997; Georgis et al., 2006; Shapiro-Ilan et al., 2006).

To kill immature stages of the large pine weevil, 3.5 million IJs are applied in a water suspension around coniferous tree stumps (Brixey et al., 2006; Dillon et al., 2006, 2007), which constitute the pest microhabitat (Leather et al., 1999). For weevil suppression on an operational level (i.e. site-wide treatment of stumps), nematodes are applied by pressure hose from a forwarder-mounted mixer tank. When inundatively applying nematodes on this scale, it is inevitable that some nematode suspension will land outside the target area (the tree stump), either as the suspension drips from the base of the pressure hose, or when operators aim at stumps from a distance e.g. when stumps are partially covered by brash and thus not readily accessible (A. Dillon, personal communication). Steinernema carpocapsae (Weiser) (Nematoda: Steinernematidae), which is commercially produced and exotic to Ireland (Hominick, 2002), is the main EPN species currently in use against $H$. abietis, though Heterorhabditis downesi Stock, Burnell and Griffin (Nematoda: Heterorhabditidae), a native Irish species (Griffin et al., 1991), has been evaluated for use against $H$. abietis in pilot trials (Dillon et al., 2006, 2007; Skrzecz and Majewski, 2010). While EPN present a promising alternative to chemical control methods and may play an important role in achieving sustainable forest management, their ability to infect and reproduce in a wide range of insects also presents a risk to non-target insects in the targeted habitat (Bathon, 1996; van Lenteren et al., 2003).

Saproxylic beetles (beetles that depend on dead or decaying wood for at least a part of their life cycle) often represent a major component of forest invertebrate communities (Speight, 1989; Siitonen, 2001; Grove, 2002; Sverdrup-Thygeson and Ims, 2002). Since standing or fallen deadwood on clearfell sites frequently contains the developing larval stages of saproxylic beetles, these insects constitute a group of potential non-target insects when controlling the pine weevil with EPN. Even small pieces $(1-15 \mathrm{~cm}$ diameter) of woody debris left behind on clearfell sites can harbor a great number and diversity of saproxylic beetles, including endangered species (Jonsell et al., 2007). With more than 25,000 species described worldwide, the cerambycids (Coleoptera: Cerambycidae), or longhorn beetles, represent one of the largest and most important groups of saproxylic beetles (Duffy, 1953; Bílý and Mehl, 1989; Twinn and Harding, 1999). Rhagium bifascia- tum Fabricius is a common cerambycid species in Ireland (Anderson et al., 1997). It is also widely distributed across Europe and is considered an endangered species in some localities (Becker, 1950; Steiner, 1999; Tozlu et al., 2010; Kuś and Kuś, 2004). The larvae take two to three years to develop (five to six larval instars are reported) and are usually found in moist pine logs and stumps in advanced stages of decomposition, though the species is highly polyphagous (Duffy, 1953; Twinn and Harding, 1999). Development and eclosion seem to be poorly synchronized and adults that eclose late in the summer (late August and September) often spend the winter in the pupation chamber to emerge in the spring of the following year (Duffy, 1953; C. Harvey, personal observation).

In addition to their direct benefits as primary bio-degraders, saproxylic beetles are host to a wide range of parasitoid wasps, for example the generalist Dolichomitus tuberculatus Geoffroy that also parasitizes $\mathrm{H}$. abietis larvae (Kenis et al., 2004; Hilszczanski et al., 2005; Hedgren, 2007). Saproxylic beetles also help sustain predatory beetles on clearfell sites (Johansson et al., 2007). Birds and other vertebrate predators that are attracted to clearfell sites by saproxylic beetles may target the adult stages of $H$. abietis (Kenis et al., 2004). In general, the greater the biodiversity and abundance of beneficial saproxylic beetles, the easier it becomes to maintain low-impact, sustainable forestry (Grove, 2002).

Extensive infection of saproxylic non-targets by EPN may not only reduce overall biodiversity and adversely affect wood decomposition on clearfell sites, it may also facilitate unwanted spread of EPN after application. Phoretic dispersal of nematodes can occur if they are carried on or within adult beetles (Downes and Griffin, 1996; Kruitbos et al., 2009). The nematodes may also recycle within non-target hosts, thereby increasing the likelihood of long-term establishment of EPN on treated sites. Steinernema feltiae Filipjev (Nematoda: Steinernematidae) is the only EPN that has been isolated from soil in mature and clearfelled Irish forests, though detection on clearfell sites is rare and populations are patchy in their distribution within sites (Griffin et al., 1991; Dillon, 2003; Dillon et al., 2008). Non-target infection and dispersal and persistence (e.g. via recycling) of inundatively applied biocontrol agents are key factors when estimating their risk and should be investigated closely when considering EPN as a potential alternative to conventional control methods (Gaugler, 1988; Bathon, 1996; Smits, 1996; van Lenteren et al., 2003).

The use of $S$. carpocapsae and $H$. downesi against the pine weevil shows promise (Brixey et al., 2006; Dillon et al., 2006) and the associated risks should therefore be evaluated. Emergence traps erected over EPN-treated and untreated stumps showed that EPN had no effect on numbers, diversity or community structure of beetles directly associated with the stumps, including the saproxylic cerambycid Asemum striatum Linnaeus (Dillon et al., 2012, under review). However, although EPN application is targeted at tree stumps, spread or inaccurate application of EPN may lead to infection of saproxylic insects in deadwood that remains on clearfell sites after felling. As one of the most abundant and conspicuous saproxylic beetles within deadwood on Irish clearfell sites (C. Harvey, personal observation), we selected $R$. bifasciatum as a representative saproxylic insect that is also a service-provider and evaluated the risk EPN present to this non-target. To this end, we examined the effects of EPN on R. bifasciatum at different levels, investigating (a) how susceptible R. bifasciatum is to IJs of S. carpocapsae and $H$. downesi in a laboratory Petri-dish assay; (b) whether EPN inundatively applied to deadwood in the laboratory and in the field infect $R$. bifasciatum within the wood (c) whether $S$. carpocapsae and H. downesi reproduce in R. bifasciatum; and (d) if R. bifasciatum are infected on clearfell sites where $S$. carpocapsae IJs have been applied to tree stumps for pine weevil suppression on an operational level. 


\section{Material and methods}

\subsection{Storage and culturing of insects and nematodes}

Waxmoth larvae, Galleria mellonella Linnaeus, used for sample baiting and nematode culturing were supplied by The Mealworm Company (Sheffield, UK) and were stored at $15^{\circ} \mathrm{C}$. S. carpocapsae (strain US-S-25) and H. downesi (strain K122) were cultured in final instar G. mellonella larvae (Kaya and Stock, 1997). IJs were collected from White traps in the first week of emergence and washed three times by allowing them to settle in tap water. IJs were two to four weeks old when used in experiments. Nematodes were stored at $9{ }^{\circ} \mathrm{C}$ at $1000 \mathrm{IJs} / \mathrm{ml}$ except those used for application to logs in laboratory and field experiments, which were stored at $9{ }^{\circ} \mathrm{C}$ in 21 flasks $(2000 \mathrm{IJs} / \mathrm{ml})$, continuously aerated and agitated by an aquarium air pump.

$R$. bifasciatum larvae, pupae and adults were collected from coniferous clearfell sites (lodgepole pine, Pinus contorta Douglas and Sitka spruce, Picea sitchensis Bongard) and were stored for up to three months at $9^{\circ} \mathrm{C}$ in 24 -well plates lined with moist tissue paper. At least two weeks before being used in experiments, larvae were transferred to a $5 \mathrm{~cm}$ diameter Petri dish filled with comminuted decomposing wood taken from logs (pine or spruce) containing $R$. bifasciatum and collected on clearfell sites not treated with EPN. Dishes were wrapped in Parafilm ${ }^{\circledR}$ (Pechiney Plastic Packaging; Menasha, USA) and kept at $20^{\circ} \mathrm{C}$. Wood was replaced once a month. Pupae and adults were also obtained by allowing larvae to pupate or eclose in Petri dishes.

\subsection{Pathogenicity assessment of EPN for R. bifasciatum (Petri dish assay)}

To assess the pathogenicity of S. carpocapsae and H. downesi to $R$. bifasciatum, IJs of either species were applied in $1 \mathrm{ml}$ of tap water to a $5 \mathrm{~cm}$ diameter Petri dish containing $5 \mathrm{~g}$ comminuted decomposing conifer wood (source same as in 2.1). A single $R$. bifasciatum larva (mid to late instar), pupa or adult was then placed in each dish. Two experiments with 10 larvae per treatment were conducted for mid to late instar larvae, with IJ concentrations of 0 (control), 50, 100, 200, and 800 in experiment 1 and 5, 10, 50, 100 and 1000 in experiment 2. Single experiments for pupae and adults were carried out using concentrations of $5,10,50,100$, 1000,5000 and 10,000 IJs for pupae and 10, 100, 1000 and 10,000 IJs for adults. Due to the limited availability of insects, especially adults and pupae, and the fact that $R$. bifasciatum are longlived and experience minimal natural mortality at $20^{\circ} \mathrm{C}$ in the laboratory (C. Harvey, personal observation), controls were only included in larval experiment 1 . EPN presence in all dead insects was confirmed by dissection. Dishes were wrapped in Parafilm and incubated at $20^{\circ}$ for 14 days. Insects were checked daily for mortality.

\subsection{Treatment of decomposing logs with EPN to assess potential for $E P N$ to infect $R$. bifasciatum within logs}

\subsubsection{Laboratory treatment of decomposing logs with EPN and assessment of $R$. bifasciatum infection within logs}

To test whether S. carpocapsae and/or H. downesi infect R. bifasciatum in their natural deadwood habitat, IJs were applied to decomposing logs (pine, spruce) in the laboratory at two concentrations. The high concentration was intended to simulate a 'worst case scenario' in which 1.8 million IJs, approximately half the number (3.5 million IJs) recommended per tree stump for pine weevil control (Brixey et al., 2006; Dillon et al., 2006), were applied to each log. The low concentration treatment $(18,000 \mathrm{IJs})$ simulated a more realistic scenario in which a piece of deadwood is hit by a small volume of nematode suspension, for example as the result of leakage from a spray nozzle or inaccurate aiming at a stump.

Three experiments were carried out in the laboratory. For each experiment, logs of $50 \mathrm{~cm}$ length were cut from deadwood (pine, spruce) that was collected on clearfell sites up to one month prior to experiments and stored in plastic bags at $4{ }^{\circ} \mathrm{C}$. Only logs of a diameter between 5 and $25 \mathrm{~cm}$ that were judged likely to contain $R$. bifasciatum were used. Such logs were typically in advanced stages of decomposition and consisted mainly of soft, spongy wood of moderate to high moisture content (occupying $\geqslant 25 \%$ of $\log$ diameter), usually with a less decomposed and hard inner core.

In laboratory experiment 1 , each treatment (control, high and low concentration of $S$. carpocapsae) included 15 logs. Each log was placed horizontally in a plastic container with a lid (measurements $60 \times 39 \mathrm{~cm}, 27 \mathrm{~cm}$ high) on a layer of moist peat moss (Westland Horticulture, Huntingdon, UK) approximately $3-4 \mathrm{~cm}$ deep. Approximately $30 \%$ of the log surface was in contact with the peat moss. Nematodes were applied suspended in $250 \mathrm{ml}$ of tap water (approximately $7000 \mathrm{IJs}$ per $\mathrm{ml}$ for high concentration, 70 IJs per $\mathrm{ml}$ for low concentration). Half of the suspension was applied along the upper surface of the log and a quarter each was applied to the peat moss along either side of the log. Control logs were treated with $250 \mathrm{ml}$ of tap water only. Containers were incubated in climate rooms at $20^{\circ} \mathrm{C}$ in the dark for 14 days, after which time logs were sampled. Since no insect mortality occurred in the control of laboratory experiment 1 and infection of insects was confirmed by dissection, no controls were included in subsequent experiments.

Dead R. bifasciatum (larvae, pupae or adults) were scored for infection by cadaver coloration (cream or brown for $S$. carpocapsae and orange, red or green for $H$. downesi) and infection was confirmed by dissection. Live insects were incubated in 24 well plates for an additional week at $20^{\circ} \mathrm{C}$ to record delayed mortality and infection. The distance between each larva and the log surface was measured, representing their depth in the wood.

Laboratory experiment 2 was of the same design as experiment 1 , but the EPN species used was H. downesi. In Laboratory experiment 3 , seven logs each were included in two treatments that received a low concentration $(18,000 \mathrm{IJs})$ of either $H$. downesi or $S$. carpocapsae.

\subsubsection{Field treatment of decomposing logs with EPN and assessment of $R$. bifasciatum infection within logs}

Two experiments similar to laboratory experiments were carried out on coniferous clearfell sites to gauge the susceptibility of $R$. bifasciatum to EPN under natural conditions. Field experiment 1 was conducted in late August 2008 at Featherbed $\left(53^{\circ} 14^{\prime} \mathrm{N}\right.$ $006^{\circ} 19^{\prime} \mathrm{W}$, elevation: $361 \mathrm{~m}$ ), two months after the site had been treated with nematodes (Table 4). Sampling of deadwood logs on this site one month after nematode application indicated no infection of $R$. bifasciatum with EPN (Table 4), either applied ( $S$. carpocapsae) or naturally occurring (S. feltiae). Due to this result and because only logs found at least $1 \mathrm{~m}$ distant from the closest treated tree stump were selected for this experiment, background infection was deemed to have no influence on experimental results. Logs (pine or spruce) distributed across the site that were judged to contain $R$. bifasciatum (see above for selection criteria) were cut to $50 \mathrm{~cm}$ length. Logs were left in situ and randomly assigned to treatments ( 10 logs each) receiving either 1.8 million or 18,000 S. carpocapsae IJs. Approximately $30 \%$ of the surface of each log was in contact with the soil. Logs were collected from the field 14 days after EPN application and stored at $4{ }^{\circ} \mathrm{C}$ until destructively sampled over the next three days. The same number of logs from each treatment was sampled each day. Other methods were the same as in laboratory experiments (2.3.1). 
Field experiment 2 was carried out in early September 2009 at Kildalkey $\left(53^{\circ} 34^{\prime} \mathrm{N}, 6^{\circ} 56^{\prime} \mathrm{W}\right.$; elevation $\left.71 \mathrm{~m}\right)$, a site not treated with EPN. Logs sourced from this and other coniferous clearfell sites (lodgepole pine or Sitka spruce logs, $50 \mathrm{~cm}$ long) were randomly assigned to one of four treatments. Logs from these sites had been previously sampled to collect $R$. bifasciatum (C. Harvey, unpublished data) and no insects infected with EPN were found, indicating that there was no background infection prior to experiments. S. carpocapsae or $H$. downesi IJs were applied in a high concentration (1.8 million IJs) to 10 logs each and in a low concentration (18,000 IJs) to eight logs each. Logs were arranged in a randomized block design within a $10 \times 100 \mathrm{~m}$ area, with each block containing one log from each treatment (two blocks with high concentration only). Logs within a block were at least $1 \mathrm{~m}$ apart and at least $1 \mathrm{~m}$ from the nearest tree stump. Blocks were at least $3 \mathrm{~m}$ apart. Other procedures were as described for field experiment 1. On the day of application, weather conditions were cloudy and dry for both experiments and air temperature was $17.5^{\circ} \mathrm{C}$ at Featherbed (experiment 1 ) and $16{ }^{\circ} \mathrm{C}$ at Kildalkey (experiment 2).

\subsection{EPN reproduction in $R$. bifasciatum}

Reproduction of $S$. carpocapsae and $H$. downesi was evaluated in mid to late instar $R$. bifasciatum larvae, the most abundant $R$. bifasciatum life stage in decomposing logs, and was compared with that in final instar G. mellonella larvae, a standard laboratory host used for EPN culturing. Individual weighed larvae of the two species were exposed to 500 IJs of $S$. carpocapsae or H. downesi applied in $500 \mu \mathrm{l}$ of tap water in Petri dishes as described for the pathogenicity assay (see above; $N=20$ per larva/EPN combination). Insects were checked for mortality every second day and dead insects were incubated for an additional 10 days in a 24-well plate before being placed on an individual White trap.

Reproduction in adults and pupae was assessed using individuals killed by EPN of either species in the $100 \mathrm{IJ}$ concentration of the pathogenicity assay (see above). Insects were transferred to a multiwell plate on the day that they died and were incubated at $20^{\circ} \mathrm{C}$ for five days before being transferred to an individual White trap. For each White trap, IJs were removed and counted weekly for eight weeks beginning one week after the first day of emergence.

2.5. Assessment of $R$. bifasciatum infection in deadwood on clearfell sites following stump treatment with $S$. carpocapsae on an operational level to control pine weevil

Deadwood was collected from six coniferous clearfell sites (pine and spruce) that had been treated with $S$. carpocapsae from a forwarder on an operational level (3.5 million IJs per stump, applied with pressure hose) between one month and one year earlier (Table 4). Criteria for selection of logs were as described for laboratory and field experiments. The shortest distance from a log to the closest stump treated with EPN was measured. Collected logs were stored at $4{ }^{\circ} \mathrm{C}$ and destructively sampled in the laboratory over the following week. The only exception was the site at Deerpark, where logs were sampled on-site. Methods for destructive sampling of logs and assessment of $R$. bifasciatum infection were the same as above (Section 2.3.1).

To determine whether infection of $R$. bifasciatum in logs on clearfell sites treated with EPN on an operational level was linked to the presence of IJs in the wood or the soil underneath logs, samples of both were baited with G. mellonella in the laboratory. Samples of $750 \mathrm{~g}$ comminuted wood were taken from each log (except for five of the logs sampled at Deerpark). Each sample was placed in a plastic bag, baited with $10 \mathrm{G}$. mellonella larvae and incubated at $20^{\circ} \mathrm{C}$ for five days, after which time insects were removed and infection was recorded. Surviving insects were incubated for two days to record delayed mortality. For five of the sampled sites, soil was taken from directly under each sampled log, each soil sample consisting of 10 pooled subsamples for a total of approximately $100 \mathrm{~g}$ of soil per log. Soil samples were stored in individual plastic bags at $4{ }^{\circ} \mathrm{C}$ for one week and then transferred into a $100 \mathrm{ml}$ plastic tub ( $8.5 \mathrm{~cm}$ diameter; Econo by Huhtamaki) with a perforated lid in which they were baited with $10 \mathrm{G}$. mellonella larvae. After seven days at $20^{\circ} \mathrm{C}$ the insects were removed and EPN infection was recorded. Surviving insects were incubated for two days at $20^{\circ} \mathrm{C}$ to record delayed EPN infection. The baiting was repeated once (i.e. each sample was baited with $20 \mathrm{G}$. mellonella in total).

\subsection{Statistics}

Statistical analysis was carried out using MiniTab Release 15 (MiniTab Solutions; Coventry, UK). The concentration of nematodes infecting $50 \%$ of insects $\left(\mathrm{LC}_{50}\right)$ and the time to $50 \%$ mortality of infected insects in a treatment $\left(\mathrm{LT}_{50}\right)$ were calculated using Probit analysis. Only insects that died were included in $\mathrm{LT}_{50}$ calculation. Data on $R$. bifasciatum infection in laboratory and field experiments are expressed as the percentage of insects that were infected with EPN in that treatment. Pairwise comparison of binomial data in $2 \times 2$ contingency tables between treatments was carried out using Pearson's $\chi^{2}$-test or, when the expected count for at least one cell was $<5$, Fisher's exact test. Binomial response variables (whether or not a larva was infected with EPN, whether or not a log sampled at Deerpark or Kilworth contained infected $R$. bifasciatum) was regressed against a continuous explanatory variable (respectively: depth in wood of larva or the distance a log was found from the nearest tree stump treated with EPN) via a logistic regression model with a Logit or Normit link function (validity confirmed by Pearson's Goodness-of-Fit test, $\alpha=0.05$ ). Pearson residuals of the model were tested for normality using the Anderson-Darling method $(\alpha=0.05)$.

Numbers of IJs emerging per mg of insect wet weight were normally distributed (Anderson-Darling test, $\alpha=0.05$ ), but did not have equal variance (Levene's test, $\alpha=0.05$ ). They were therefore compared using Student's two sample t-test $(\alpha=0.05)$, which is robust against inequal variance when sample size is identical among data sets (Markowski and Markowski, 1990). Linear trends for EPN emergence in the reproduction experiment were compared by running a General Linear Model (GLM) on the logarithm of the number of IJs emerging each week, in which the week of emergence and the cadaver type (e.g. $R$. bifasciatum larvae) were used as interacting predictors. If the null hypothesis for the interaction is rejected, then slopes of the linear trends are not equal (Neter et al., 1996).

\section{Results}

\subsection{Pathogenicity assessment of EPN for R. bifasciatum (Petri dish assay)}

The $S$. carpocapsae $\mathrm{LC}_{50}$ for $R$. bifasciatum larvae was $29 \mathrm{IJs}$ in experiment 1 and 36 IJs in experiment 2, values similar to those obtained for $H$. downesi (24 IJs and 42 IJs, respectively) (Table 1). There was no significant difference in the $\mathrm{LC}_{50}$ between EPN species (95\% CI overlap, Table 1 ). Mortality of pupae was $\geqslant 6$ out of 10 individuals at the lowest EPN concentration used (5 IJs) and the $\mathrm{LC}_{50}$ was estimated as $1 \mathrm{IJ}$ for both $\mathrm{S}$. carpocapsae and $\mathrm{H}$. downesi (Table 1). Similarly, at least half of $R$. bifasciatum adults were killed by EPN at the lowest IJ concentration (10 IJs) and all adults died at a concentration of $100 \mathrm{IJs}$ and above. The $\mathrm{LC}_{50}$ for this life stage was therefore estimated to be $<10$ IJs (Table 1 ).

At a concentration of $100 \mathrm{IJs}$, the $\mathrm{LT}_{50}$ for larvae exposed to $H$. downesi was approximately two days longer than for S. carpocapsae 
in both experiments (experiment 1: 5.7 days vs. 3.6 days; experiment 2: 7.2 days vs. 4.8 days), a difference that was significant in both cases (no 95\% CI overlap, Table 1). The $\mathrm{LT}_{50}$ for larvae at 1000 IJs was similar for the two EPN species (Table 1). The $\mathrm{LT}_{50}$ for pupae was similar to that for larvae, except for $H$. downesi at 1000 IJs, where larvae died significantly quicker than pupae (no 95\% CI overlap, Table 1). Adults were the quickest to die when exposed to $100 \mathrm{IJs}$, with an $\mathrm{LT}_{50}$ of no more than 3.5 days, significantly shorter than for larvae and pupae (no 95\% CI overlap, Table 1). All adults exposed to 1000 IJs of S. carpocapsae or H. downesi died within three days, and the $\mathrm{LT}_{50}$ was estimated to be $<3$ days in each case (Table 1 ), again lower than for either larvae or pupae.

\subsection{Treatment of decomposing logs with EPN to assess potential for $E P N$ to infect $R$. bifasciatum within logs}

Two weeks after EPN application, infected $R$. bifasciatum were found within logs in both laboratory and field experiments. Infection at both high $(1.8$ million) and low $(18,000)$ IJ concentrations generally was higher in laboratory experiments than in field experiments (Table 2). At a high IJ concentration, 90\% of insects were infected in the laboratory, compared with $67-71 \%$ in the field. In low concentration treatments, infection was $19-62 \%$ in the laboratory and below $12 \%$ in the field (Table 2 ).

Pairwise comparison of the infection of $R$. bifasciatum larvae between treatments within experiments showed that EPN species had no significant effect on infection $\left(\chi^{2}\right.$-test or Fisher's exact test, $P>0.05)$, but that the concentration of EPN did $\left(\chi^{2}\right.$-test, $P<0.001$; Table 2 and Appendix A.1). Cross-comparison of larval infection between corresponding treatments in field and laboratory experiments (i.e. same EPN species and concentration) revealed a significant effect of experimental setting in eight out of nine pairwise comparisons $\left(\chi^{2}\right.$-test, $P<0.05$; $S$. carpocapsae low concentration in laboratory experiment 1 vs. field experiment $2: P>0.05$; Table 2 and Appendix A.2).

3.2.1. Effect of developmental stage on susceptibility of $R$. bifasciatum Presence and abundance of $R$. bifasciatum adults, pupae and larvae in logs was highly variable between experimental treatments (Table 2). Thus, to test for an overall difference in nematode infection among life stages for each EPN species ( $S$. carpocapsae or H. downesi), data were combined across all treatments (laboratory and field experiments) in which all three $R$. bifasciatum life stages were represented (Table 2). Larval infection was lower than pupal infection and similar to adult infection for $S$. carpocapsae (larvae: 106 infected, 303 total [35\%]; pupae: 25/43 [58\%]; adults: 14/37 [38\%]) and life stage had a significant effect on infection $\left(\chi_{2}^{2}=8.583, P=0.014\right)$. For $H$. downesi, larvae were less frequently infected than pupae or adults (larvae: 160/234, 68\%; pupae: 11/13, 85\%; adults: $50 / 58,86 \%$ ), with life stage again having a significant effect on infection $\left(\chi_{2}^{2}=8.411, P=0.015\right)$. Similar trends were observed when data were combined in the same way for each experimental setting separately (laboratory or field) (Table 2).

\subsubsection{Infection of R. bifasciatum larvae in relation to their depth in wood}

Infected $R$. bifasciatum larvae were found at depths of up to $5.1 \mathrm{~cm}$ in the wood of logs (Fig 1). When infection of larvae (yes or no) was regressed against their depth in the wood in a logistic model, there was a significant trend for EPN infection to decrease with increasing depth in wood for $S$. carpocapsae (slope: -0.15 , $Z=-2.17, P=0.030 ; N=645$ ), but not for $H$. downesi (slope: $-0.05, Z=-0.42, P=0.674 ; N=291$ ) (data from laboratory and field experiments combined for each EPN species; Fig 1).

\subsection{EPN reproduction in $R$. bifasciatum}

Both of the investigated EPN species reproduced in R. bifasciatum larvae, pupae and adults infected in the laboratory. More than 120,000 IJs emerged per larva infected with $S$. carpocapsae and approximately half that number $(69,000 \mathrm{IJs})$ emerged from larvae infected with $H$. downesi over eight weeks (Table 3 ). On average, $117,200(\mathrm{SE} \pm 17,600) H$. downesi IJs emerged per adult and $115,600(\mathrm{SE} \pm 20,900) H$. downesi IJs emerged per pupa infected in the pathogenicity assay ( $N=9$ for each). The number of $S$. carpocapsae IJs emerging was lower for these two life stages, with approximately 63,200 ( $\mathrm{SE} \pm 14,700)$ IJs per adult $(N=10)$ and $23,900(\mathrm{SE} \pm 19,000)$ IJs per pupa $(N=8)$.

For both EPN species, the number of IJs that emerged per mg of insect wet weight was significantly lower for $R$. bifasciatum larvae than it was for $G$. mellonella larvae ( $t$-test; $S$. carpocapsae: $T_{38}=-3.90, P<0.001 ; H$. downesi: $T_{38}=6.48, P<0.001$ ) (Table 3 ). The number of $S$. carpocapsae IJs emerging from $R$. bifasciatum larvae per mg of wet weight was higher than for larvae infected with $H$. downesi, but the difference was not significant (t-test; $T_{38}=-1.20, P=0.120$ ) (Table 3 ). The slopes of the linear trends for the number of $H$. downesi and $S$. carpocapsae IJs emerging weekly from $R$. bifasciatum larvae differed significantly (GLM; $F_{1}=7.37, P=0.007$ ) and Fig 2 indicates that emergence of $H$. downesi decreased more rapidly than that of $S$. carpocapsae. Slopes of the linear trends for R. bifasciatum and G. mellonella larvae differed significantly for both EPN species (GLM, S. carpocapsae: $F_{1}=28.52$, $P<0.001$; H. downesi: $F_{1}=14.66, P<0.001$; Fig 2$)$ and in both cases, emergence from $G$. mellonella decreased more rapidly than emergence from $R$. bifasciatum (Fig 2).

3.4. Assessment of R. bifasciatum infection in deadwood on clearfell sites following stump treatment with S. carpocapsae on an operational level to control pine weevil

Overall, of the 113 logs that were sampled across the six clearfell sites, $8.8 \%$ contained $R$. bifasciatum infected with $S$. carpocapsae and of the total 1989 R. bifasciatum individuals (1683 larvae, 289 pupae, 17 adults) that were found, 3.9\% were infected (Table 4). We did not detect $R$. bifasciatum infected with $S$. carpocapsae at 3 of the 6 sites sampled (Lackenrea, Ballymacshaneboy, Raheenkyle), but infected larvae were found at the remaining three sites (Kilworth, Featherbed, Deerpark) (Table 4).

At Featherbed, no infection was recorded 1 month after nematode application, but a single infected larva was found on a second sampling 12 months after nematode application (Table 4). At Kilworth, sampled one month after EPN application, 7.4\% of R. bifasciatum individuals within logs were infected and at Deerpark, sampled one year after EPN application, infection was 10.3\%. Some infection was recorded in approximately a third of the sampled logs on each of these two sites (Table 4) and the percentage of infected $R$. bifasciatum individuals within an individual log ranged from $1.8 \%$ (Kilworth) to $54.5 \%$ (Deerpark) (Fig 3).

All but one of the logs from Kilworth and Deerpark in which $R$. bifasciatum were infected had been found within $60 \mathrm{~cm}$ of the nearest treated tree stump (Fig 3). The likelihood of a log containing infected $R$. bifasciatum decreased significantly with increasing distance from treated tree stumps (presence or absence of infection in log regressed against logarithm of distance from stump; slope $=-1.78, Z=2.20, P=0.028)($ Fig 3$)$. The same was true when only those logs within $1 \mathrm{~m}$ of a tree stump were included in analysis (no transformation of data, slope $=-0.05, Z=2.62, P=0.009$ ).

EPN were detected in bulk wood samples from 5 of 12 logs (42\%) at Kilworth and 4 of 16 logs (25\%) at Deerpark by baiting samples with G. mellonella larvae (Table 4), but not all of these logs also contained infected $R$. bifasciatum (Table 4 ). EPN were detected 
Table 1

$\mathrm{LC}_{50}$ and $\mathrm{LT}_{50}$ (with $95 \%$ confidence intervals) of $S$. carpocapsae and $H$. downesi for $R$. bifasciatum larvae, pupae and adults in Petri dish bioassays. Estimates marked with an asterisk were significant (slope and intercept of fit $P<0.05$ ). $\mathrm{LC}_{50}$ and $\mathrm{LT}_{50}(1000 \mathrm{IJs}$ ) for adults are imprecise, since mortality in these cases was $>50 \%$ at the lowest EPN concentrations and $100 \%$ within three days of exposure.

\begin{tabular}{|c|c|c|c|}
\hline \multirow[t]{2}{*}{ Nematode species/R. bifasciatum life stage } & \multicolumn{3}{|c|}{$\mathrm{LC}_{50}$ (IJs) and $\mathrm{LT}_{50}$ (days) at 100 and $1000 \mathrm{IJs}$ per insect (95\% CI in brackets) } \\
\hline & $\mathrm{LC}_{50}$ & $\mathrm{LT}_{50} 100 \mathrm{IJs}$ & $\mathrm{LT}_{50} 1000 \mathrm{IJs}$ \\
\hline \multicolumn{4}{|l|}{ S. carpocapsae } \\
\hline Larvae (exp. 1) & $29 *(6-72)$ & $3.6^{*}(3.0-4.3)$ & $\mathrm{N} / \mathrm{A}$ \\
\hline Larvae (exp. 2) & $36^{*}(16-89)$ & $4.8^{*}(3.9-5.5)$ & $3.6^{*}(3.1-7.8)$ \\
\hline Pupae & $1(0-7)$ & $6.3^{*}(5.3-7.2)$ & $4.4^{*}(1.7-6.0)$ \\
\hline Adults & $<10$ & $3.5 *(3.1-3.9)$ & $<3$ \\
\hline \multicolumn{4}{|l|}{ H. downesi } \\
\hline Larvae (exp. 1) & $24^{*}(5-62)$ & $5.7^{*}(4.7-6.5)$ & $\mathrm{N} / \mathrm{A}$ \\
\hline Larvae (exp. 2) & $42 *(0-97)$ & $7.2 *(6.1-8.3)$ & $3.0^{*}(2.6-3.4)$ \\
\hline Pupae & $1(0-6)$ & $6.6^{*}(5.4-7.7)$ & $5.6^{*}(4.5-6.5)$ \\
\hline Adults & $<10$ & $3.2 *(2.8-3.6)$ & $<3$ \\
\hline
\end{tabular}

in soil samples from under three of the logs sampled at Kilworth, all of which also contained infected $R$. bifasciatum (Table 4). Two soil samples collected at Deerpark were positive for EPN, one of which was from below a log containing infected $R$. bifasciatum. Nematodes were detected in soil samples from two additional sites (Featherbed and Raheenkyle; Table 4) without $R$. bifasciatum infection.

\section{Discussion}

All of the R. bifasciatum life stages that were tested - mid to late instar larvae, pupae and adults - were susceptible to infection with S. carpocapsae and $H$. downesi. Larvae were the least susceptible, with $\mathrm{LC}_{50}$ (24-42 IJs) and $\mathrm{LT}_{50}$ (4-7 days) similar to what has been reported for larvae of other xylophagous beetles, including the target pest $H$. abietis (Pye and Burman, 1977, 1978; Lindegren et al., 1981; Solter et al., 2001; Fallon et al., 2004). R. bifasciatum adults were especially vulnerable to EPN infection $\left(\mathrm{LC}_{50}<10 \mathrm{IJs}\right.$, $\mathrm{LT}_{50} \leqslant 3$ days at $1000 \mathrm{IJs}$ ), considerably more so than adults of $H$. abietis, which had an $\mathrm{LT}_{50}$ of over 4 days at concentrations of up to $4000 \mathrm{IJs}$ for both $\mathrm{S}$. carpocapsae and $\mathrm{H}$. downesi and showed only $57 \%$ mortality after 10 days exposure to $4000 \mathrm{H}$. downesi IJs (Girling et al., 2010). In our laboratory and field experiments, larvae inside deadwood logs were less frequently infected with $H$. downesi and $S$. carpocapsae than pupae and (for $\mathrm{H}$. downesi) also adults, reflecting a trend similar to that observed in the Petri dish assay.

The high susceptibility of all stages of $R$. bifasciatum to EPN demonstrated in the pathogenicity assay suggests that even small amounts of the highly concentrated IJ suspension (3.6 million IJs per stump, approximately 7000 IJs per ml; Dillon et al., 2006) that is used to treat tree stumps against $H$. abietis on an operational level contain enough IJs to potentially kill a large number of $R$. bifasciatum. It therefore was not surprising that, after treatment of decomposing logs with half that number of IJs (1.8 million IJs, approximately $7000 \mathrm{IJs}$ per $\mathrm{ml}$ ) under laboratory incubation at the same temperature and for the same duration as the pathogenicity assay, both $S$. carpocapsae and $H$. downesi infected $R$. bifasciatum larvae, pupae and adults inside the logs. However, even in this 'worst-case scenario' not all $R$. bifasciatum were infected and in logs treated with one hundredth the number of the IJs $(18,000$ or 70 per $\mathrm{ml}$ ) in the laboratory, simulating accidental spillage of nematode suspension, infection was below $40 \%$ in three out of four experimental treatments. Moreover, infection of $R$. bifasciatum in field experiments was significantly reduced when compared with the laboratory, with little $(<11 \%)$ or no infection found in 18,000 IJ treatments. This was probably due to low temperatures and other abiotic or biotic stressors that adversely affected IJ survival, movement and infectivity in the field (Shamseldean and AbdElgawad, 1995; Saunders and Webster, 1999; Lewis et al., 2006). Thus, the risk to R. bifasciatum in the field is expected to be low in a scenario in which deadwood logs or woody debris are only occasionally hit by small amounts of IJ suspension when treating clearfell sites with EPN.

Yet, even if initial infection of $R$. bifasciatum is low, reproduction and subsequent establishment and spread of inundatively applied EPN may pose a long-term risk to this and other deadwood-associated insects (Bathon, 1996; van Lenteren et al., 2003). While

Table 2

Percentage of R. bifasciatum infected by S. carpocapsae or H. downesi within logs in each of the experiments conducted in the laboratory (Lab) and the field (Field). Totals for laboratory and field experiments given in bottom rows for each nematode species (all treatments except control). Only logs containing $R$. bifasciatum ( $\mathrm{N}$ ) included.

\begin{tabular}{|c|c|c|c|c|c|c|c|}
\hline \multirow[t]{2}{*}{ Experiment } & \multirow[t]{2}{*}{ EPN species } & \multirow[t]{2}{*}{ EPN conc. (IJs) } & \multirow[t]{2}{*}{$N$} & \multicolumn{3}{|c|}{ Percentage of $R$. bifasciatum life stages infected (infected/total) } & \multirow[t]{2}{*}{ Overall percentage infected } \\
\hline & & & & Larvae & Pupae & Adults & \\
\hline \multirow[t]{3}{*}{ Lab I } & Sc & $1,800,000$ & 14 & $89.4(67 / 75)$ & - & $100(18 / 18)$ & 90.4 \\
\hline & & 18,000 & 11 & $19.3(6 / 31)$ & - & - & 19.3 \\
\hline & & 0 (control) & 14 & $0(0 / 55)$ & - & $0(0 / 12)$ & 0 \\
\hline \multirow[t]{2}{*}{ Lab II } & $H d$ & $1,800,000$ & 14 & $85.9(67 / 78)$ & 85.7 (6/7) & $88.5(23 / 26)$ & 90.1 \\
\hline & & 18,000 & 15 & $50.0(41 / 82)$ & $100(4 / 4)$ & $90.0(18 / 20)$ & 61.8 \\
\hline \multirow[t]{2}{*}{ Lab III } & Sc & 18,000 & 7 & $32.8(19 / 58)$ & $25.0(1 / 4)$ & $0.0(0 / 1)$ & 31.7 \\
\hline & $H d$ & 18,000 & 7 & $32.0(16 / 50)$ & - & $50.0(1 / 2)$ & 32.7 \\
\hline \multirow[t]{2}{*}{ Field I } & Sc & $1,800,000$ & 10 & $75.2(85 / 113)$ & $50.9(28 / 55)$ & - & 67.3 \\
\hline & & 18,000 & 10 & $1.69(2 / 118)$ & $33.3(5 / 15)$ & $14.3(2 / 14)$ & 6.1 \\
\hline \multirow[t]{4}{*}{ Field II } & Sc & $1,800,000$ & 10 & $66.9(85 / 127)$ & $79.2(19 / 24)$ & $54.5(12 / 22)$ & 67.1 \\
\hline & & 18,000 & 8 & $8.5(5 / 59)$ & - & $25.0(3 / 12)$ & 11.3 \\
\hline & $H d$ & $1,800,000$ & 8 & $70.3(52 / 74)$ & $50.0(1 / 2)$ & $75.0(9 / 12)$ & 70.5 \\
\hline & & 18,000 & 7 & $0(0 / 31)$ & - & $0(0 / 12)$ & 0 \\
\hline \multirow[t]{2}{*}{ Total } & Sc & $\mathrm{N} / \mathrm{A}$ & 52 & $46.3(269 / 581)$ & $54.1(53 / 98)$ & $52.2(35 / 67)$ & 47.9 \\
\hline & $H d$ & N/A & 51 & $50.0(139 / 278)$ & $70.6(12 / 17)$ & $70.8(51 / 72)$ & 55.0 \\
\hline
\end{tabular}


S. carpocapsae and $H$. downesi reproduced in $R$. bifasciatum larvae less efficiently than in larvae of culturing host $G$. mellonella, the two EPN species produced between 24,000 and 120,000 IJs on average per infected $R$. bifasciatum larva, pupa or adult. These numbers fall well within the range reported in the literature for other xylophagous beetles, for example the Asian longhorn beetle Anoplophora glabripennis Motchulsky (Solter et al., 2001; Fallon et al., 2004) and also the targeted pest insect $H$. abietis (Dillon, 2003). The ability of $S$. carpocapsae and $H$. downesi to reproduce in $R$. bifasciatum indicates that even a low number of initially infected individuals could result in extensive secondary infestation of the surrounding wood with thousands of IJs. However, since EPN were detected in the wood of three logs at Deerpark and Kilworth that contained no infected $R$. bifasciatum, it appears that EPN presence in the wood does not necessarily lead to infection of insects within that $\log$.

Interestingly, emergence of $S$. carpocapsae from $R$. bifasciatum hosts was protracted, with thousands of IJs emerging even in the eighth week of emergence, whereas emergence from cadavers infected with $H$. downesi effectively ceased within four weeks. The reason for this difference is unknown, though it highlights that reproduction patterns in non-target hosts and therefore also the potential for persistence may differ substantially between EPN species used for biological control. Protracted emergence of
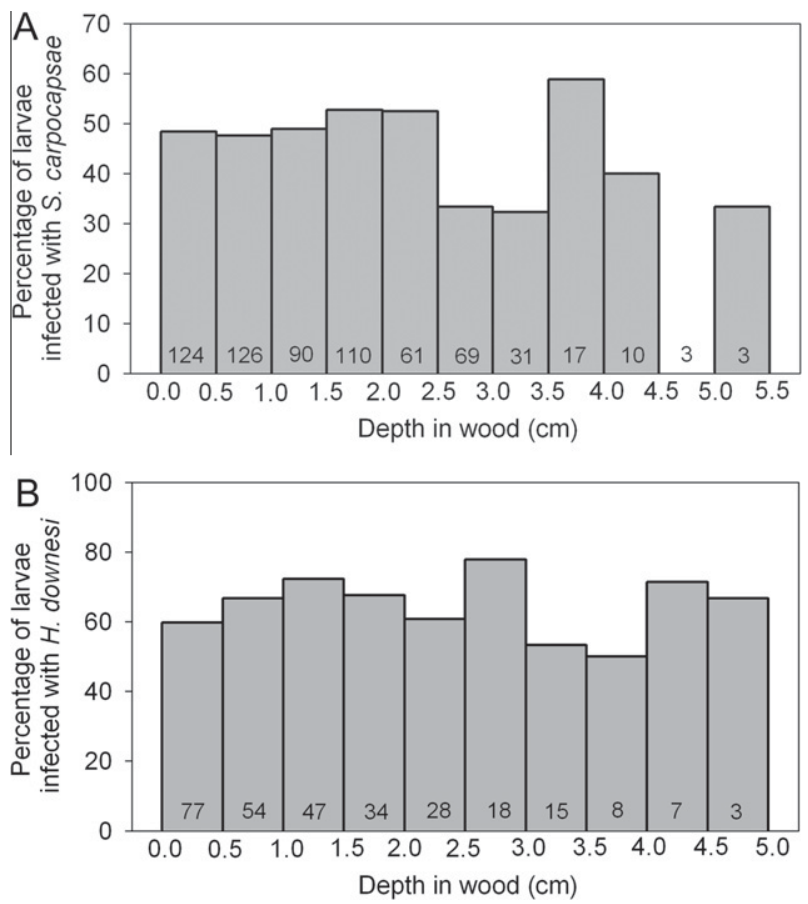

Fig. 1. Percentage of $R$. bifasciatum larvae infected by S. carpocapsae (A) or $H$. downesi (B) with increasing depth in the wood of logs in laboratory and field experiments (for each EPN species, data for all treatments was combined). Data is grouped by distance intervals of $0.5 \mathrm{~cm}$. A significant decrease in larval infection with increasing distance was found for $S$. carpocapsae (logistic regression, $P=0.030$ ), but not $H$. downesi $(P=0.674)$. Numbers inside bars give $N$. One datum point (live larva found at $7.3 \mathrm{~cm}$ depth in a $S$. carpocapsae treatment) is not included in the graph.
S. carpocapsae IJs may prolong persistence of S. carpocapsae within deadwood as the wood is inoculated with freshly emerged IJs for several weeks after a $R$. bifasciatum larva has been infected. Additionally, IJs that do not immediately emerge and remain in the host cadaver are protected from abiotic stressors such as cold or desiccation, which may allow them to survive adverse conditions, including winter (Brown and Gaugler, 1997). However, recycling of nematodes within logs may be adversely affected by competition with viral, bacterial or fungal pathogens or other nematodes within the host cadaver (Kaya and Koppenhöfer, 1996; Duncan et al., 2003) and simple Petri-dish assessments of recycling may therefore greatly overestimate what occurs in nature.

Since adult $R$. bifasciatum are active flyers (C. Harvey, personal observation) and EPN reproduced within this life stage, they may act as vehicles for phoretic dispersal and spread of EPN when infected (Downes and Griffin, 1996). However, given that EPN are usually applied on clearfell sites in late spring to mid-summer (Brixey et al., 2006; Dillon et al., 2006), after most $R$. bifasciatum adults that overwintered within logs have already emerged from deadwood (Duffy, 1953), the risk of phoretic dispersal of EPN by infected adults is expected to be low. We found no R. bifasciatum infected with naturally occurring $S$. feltiae in the deadwood sampled for the present study, indicating that this insect is not instrumental in sustaining local EPN populations. We therefore do not expect applied S. carpocapsae to have a significant impact on local $S$. feltiae populations due to direct competition for $R$. bifasciatum hosts.

S. carpocapsae and H. downesi caused similar amounts of R. bifasciatum infection within deadwood in our laboratory and field experiments, and even though infection with $S$. carpocapsae decreased the deeper larvae were located in the wood, IJs of both EPN species infected larvae at depths greater than $4.5 \mathrm{~cm}$. This

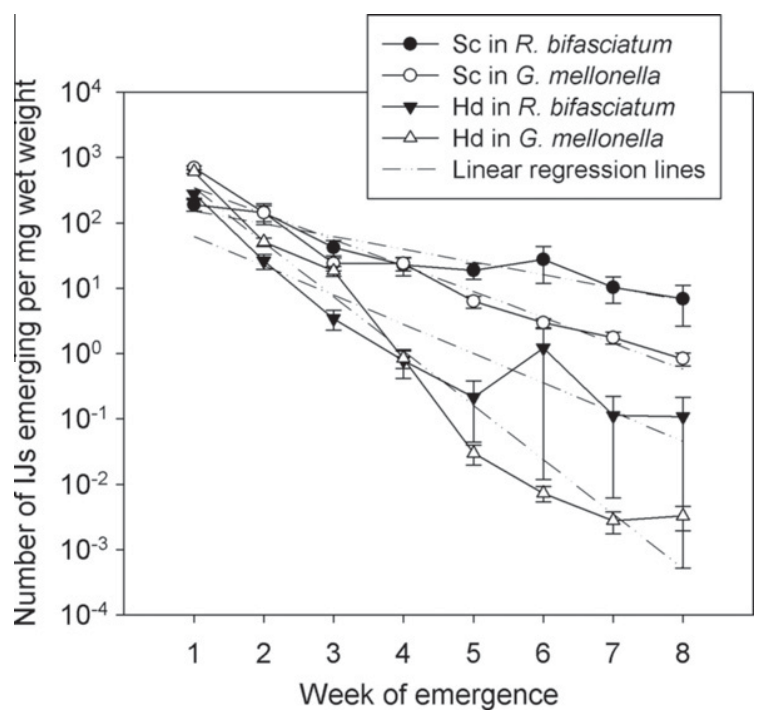

Fig. 2. Mean number of S. carpocapsae (Sc) and H. downesi (Hd) IJs emerging weekly from $R$. bifasciatum and G. mellonella larvae per mg of insect wet weight. Error bars represent standard error.

Table 3

Mean $( \pm)$ number of infective juveniles of $S$. carpocapsae and $H$. downesi emerging from $R$. bifasciatum and G. mellonella larvae infected in the laboratory over eight weeks $(N=20)$.

\begin{tabular}{lllll}
\hline EPN species & Host & Mean host weight in mg $( \pm$ SE $)$ & Mean number of IJs/host $( \pm$ SE $)$ & Mean number of IJs per mg wet weight $( \pm$ SE $)$ \\
\hline S. carpocapsae & R. bifasciatum & $282.6( \pm 20.0)$ & $120,153( \pm 20,900)$ & $461.4( \pm 82.2)$ \\
& G. mellonella & $244.8( \pm 12.8)$ & $206,731( \pm 16,941)$ & $878.7( \pm 82.4)$ \\
H. downesi & R. bifasciatum & $212.7( \pm 13.2)$ & $68,660( \pm 11,552)$ & $309.1( \pm 40.7)$ \\
& G. mellonella & $228.0( \pm 12.4)$ & $150,756( \pm 8459)$ & $677.5( \pm 36.5)$ \\
\hline
\end{tabular}


indicates that although $H$. downesi invaded the iterior of the logs $(>2.5 \mathrm{~cm}$ depth) more effectively than $S$. carpocapsae, some IJs of S. carpocapsae penetrated the deadwood as effectively as $\mathrm{H}$. downe$s i$. This may seem unexpected based on the established paradigm of EPN foraging strategy, according to which S. carpocapsae is generally classified as an 'ambusher' species with limited dispersal and host seeking behavior and no attraction to host volatiles at a distance (Grewal et al., 1994; Lewis et al., 1995, 2006). By contrast, H. downesi - like many heterorhabditids - is considered a 'cruiser' EPN species (Dillon et al., 2006; Lewis et al., 2006) that actively seeks out cryptic or sedentary hosts, for example by moving toward volatiles emitted by the potential host (Grewal et al., 1994; Boff et al., 2001; Lewis et al., 2006). Despite its reputation as an 'ambusher', S. carpocapsae has been used successfully against wood-boring pest beetles in natural and laboratory settings (Lindegren et al., 1981; Fallon et al., 2004; Dillon et al., 2006). Moreover, there is evidence to suggest that the dispersal of IJs, including those of $S$. carpocapsae, depends to a large degree on substrate texture (Georgis and Poinar, 1983; Molyneux and Bedding, 1984; Portillo-Aguilar et al., 1999; Jabbour and Barbercheck, 2008). In laboratory assays, S. carpocapsae IJs moved through peat soil as

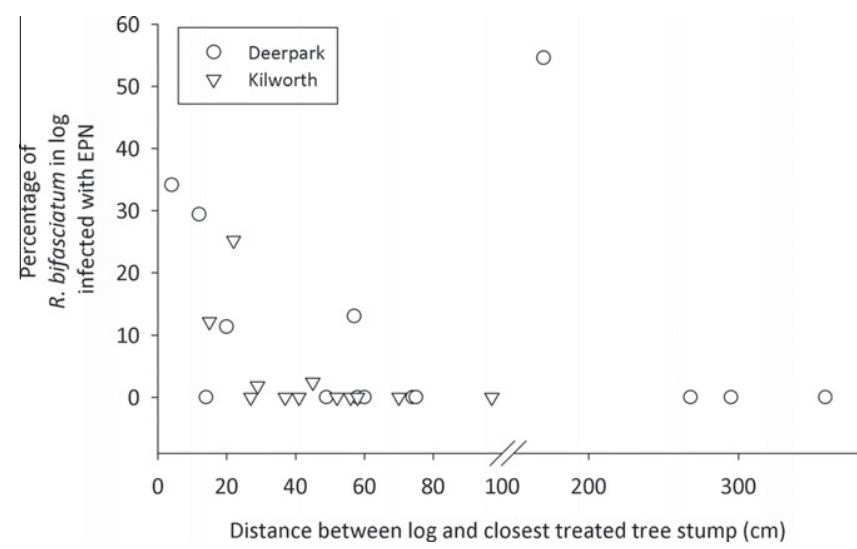

Fig. 3. Percentage of $R$. bifasciatum infected within logs sampled on two clearfell sites (Deerpark and Kilworth) with stumps treated with S. carpocapsae (y) plotted against distance between the $\log$ and the closest tree stump treated with $S$. carpocapsae (x). Each symbol represents a log sampled at one of the two sites one month (Kilworth) or one year (Deerpark) after nematode application. effectively as IJs of cruiser species Heterorhabditis megidis (Kruitbos et al., 2010) and they moved through $R$. bifasciatum frass as effectively as IJs of $H$. downesi (C. Harvey, unpublished data). Steinernema carpocapsae IJs (as well as those of $S$. feltiae and $H$. megidis) have been found to aggregate in response to vibrations (Torr et al., 2004) and frass galleries within the wood may provide routes for IJs to follow to the feeding insects at their terminus (Lindegren et al., 1981), just as plant roots can serve as routeways to host insects (Ennis et al., 2010). The nature of the substrate, host associated cues and routeways in the wood may explain why, in our experiments, IJs of $S$. carpocapsae penetrated logs and infected $R$. bifasciatum within the wood to the extent they did.

Deadwood sampled one year after $S$. carpocapsae application at Deerpark contained S. carpocapsae IJs and infected R. bifasciatum. Due to the relatively long time interval between EPN application and sampling, it is likely these IJs resulted from recycling within logs rather than being survivors of the IJs originally applied on this site. Recycling may have occurred either in the months following application and/or in the spring preceding sampling. Judging from the occurrence of infected $R$. bifasciatum along with the nematodes detected in wood at that time, the latter is likely. Overall, however, fewer than $4 \%$ of $R$. bifasciatum individuals in logs from clearfell sites on which $S$. carpocapsae was applied to tree stumps were infected. On the majority of sampled sites, infection of $R$. bifasciatum or presence of $S$. carpocapsae in wood samples was either rare (Featherbed) or not recorded at all (Lackenrea, Ballymacshaneboy, Raheenkyle). At Kilworth and Deerpark, where infection of $R$. bifasciatum with $S$. carpocapsae was more extensive, the likelihood of finding infected insects within a log decreased significantly with increasing distance between logs and treated tree stumps. This suggests that the more accurate the application of EPN around tree stumps, the lower the likelihood of non-target saproxylic insects in deadwood being infected. Since EPN were detected in some of the soil samples collected from underneath sampled logs, migration of IJs from the point of inundative application (i.e. the tree stump) to logs close by could account for some of the infection of $R$. bifasciatum. However, studies indicate that the horizontal dispersal of $S$. carpocapsae IJs in soil on clearfell sites is limited to such a degree (Dillon et al., 2008, C. Harvey, unpublished data) that this seems an unlikely explanation for the amount of infection recorded at Kilworth and Deerpark one month and one year after EPN application, respectively. Spillage or inaccurate application of IJ suspension is

Table 4

Infection of R. bifasciatum (larvae, pupae and adults combined) in deadwood logs from six clearfell sites treated with S. carpocapsae.

\begin{tabular}{|c|c|c|c|c|c|c|}
\hline \multirow[t]{2}{*}{ Site with coordinates and elevation } & \multirow{2}{*}{$\begin{array}{l}\text { Number of months } \\
\text { between sampling } \\
\text { and EPN application }\end{array}$} & \multirow[t]{2}{*}{ Logs sampled } & \multicolumn{2}{|c|}{$\begin{array}{l}\text { Percentage of logs with EPN } \\
\text { detected in }\end{array}$} & \multirow[t]{2}{*}{$\begin{array}{l}\text { Percentage of } R \text {. bifasciatum } \\
\text { infected (inf./total) }\end{array}$} & \multirow[t]{2}{*}{$\begin{array}{l}\text { Percentage of logs with } \\
\text { infected } R \text {. bifasciatum }\end{array}$} \\
\hline & & & Soil under log & Wood from log & & \\
\hline $\begin{array}{l}\text { Kilworth } \\
\qquad 52^{\circ} 10^{\prime} \mathrm{N} \\
008^{\circ} 08^{\prime} \mathrm{W} 255 \mathrm{~m}\end{array}$ & 1 & 12 & $25(3 / 12)$ & $41(5 / 12)$ & $7.4(38 / 512)$ & $33(4 / 12)$ \\
\hline Featherbed & 1 & 15 & 0 & 0 & $0(0 / 413)$ & 0 \\
\hline $\begin{array}{l}53^{\circ} 14^{\prime} \mathrm{N} \\
006^{\circ} 19^{\prime} \mathrm{W} 361 \mathrm{~m}\end{array}$ & 12 & 15 & $20(3 / 15)$ & 0 & $0.4(1 / 238)$ & $7(1 / 15)$ \\
\hline $\begin{array}{l}\text { Raheenkyle } \\
\quad 52^{\circ} 18^{\prime} \mathrm{N} \\
008^{\circ} 34^{\prime} \mathrm{W} 426 \mathrm{~m}\end{array}$ & 1 & 15 & $13(2 / 15)$ & 0 & $0(0 / 349)$ & 0 \\
\hline $\begin{array}{l}\text { Lackenrea } \\
\qquad 52^{\circ} 08^{\prime} \mathrm{N} \\
007^{\circ} 48^{\prime} \mathrm{W} 53 \mathrm{~m}\end{array}$ & 2 & 20 & 0 & 0 & $0(0 / 70)$ & 0 \\
\hline $\begin{array}{l}\text { Ballymac shaneboy } \\
\quad 52^{\circ} 18^{\prime} \mathrm{N} \\
008^{\circ} 36^{\prime} \mathrm{W} 311 \mathrm{~m}\end{array}$ & 2 & 20 & 0 & 0 & $0(0 / 27)$ & 0 \\
\hline $\begin{array}{l}\text { Deerpark } \\
\quad 53^{\circ} 09^{\prime} \mathrm{N} \\
006^{\circ} 12^{\prime} \mathrm{W} 319 \mathrm{~m}\end{array}$ & 12 & 16 & $13(2 / 16)$ & $25(4 / 16)$ & $10.3(39 / 380)$ & $31(5 / 16)$ \\
\hline Total & & 113 & & & $3.9(78 / 1989)$ & $9(10 / 113)$ \\
\hline
\end{tabular}


more likely to account for the initial infestation of logs and EPN presence in soil below logs. Recycling through $R$. bifasciatum and possibly other hosts within logs then allowed EPN to persist into the following spring at Deerpark.

Our results indicate that $S$. carpocapsae and H. downesi used for biological control on clearfell sites pose little risk to saproxylic non-target insects in deadwood and woody debris. Though both EPN species penetrated deadwood and infected larvae, pupae and adults of the representative wood-decomposer $R$. bifasciatum, consistently high levels of infection were only recorded when a 'worst case scenario' (1.8 million IJs per log) was simulated. Low concentrations of IJs $(18,000)$ had little adverse effect on $R$. bifasciatum in the field. Nevertheless, due to the ability of both of the investigated EPN species to reproduce within this non-target host, even a single infected insect might theoretically suffice as the source for an eventual infestation of an entire log. Such concerns raised by the results of laboratory experiments are alleviated to a large degree by results from the field that indicated little overall infection of $R$. bifasciatum on clearfell sites treated with $S$. carpocapsae on a site-wide operational level. Where it was recorded, infection was most likely the result of accidental spillage and/or inaccurate application of EPN around tree stumps - factors which can be minimized by more accurate application techniques (e.g. brash removal prior to nematode application) and/or equipment. We conclude that, when EPN application for inundative pest control is targeted specifically at the target pest microhabitat as in the case of the large pine weevil (i.e. application around tree stumps), this strongly limits the risk to non-target insects and the likelihood of unwanted recycling or phoretic dispersal of the nematodes through such hosts.

\section{Acknowledgments}

We thank the Irish Environmental Protection Agency (EPA) and the Department of Environment, Heritage and Local Government (DoEHLG) for support. This study was funded by the EPA STRIVE programme (project code 2007-PhD-B-6) under the National Development Plan 2007-2013. Nematodes were applied under license (TA003) from the Pesticide Control Services of the Irish Department of Agriculture and Food. Coillte Teoranta provided clearfell sites and Dr Aoife Dillon at the Coillte Forest Protection Section provided information and technical advice on the sites. We thank the two anonymous reviewers for their comments and suggestions on an earlier version of the manuscript.

\section{Appendix A. Supplementary data}

Supplementary data associated with this article can be found, in the online version, at http://dx.doi.org/10.1016/j.biocontrol. 2012.04.002.

\section{References}

Anderson, R., Nash, R., O'Connor, J.P., 1997. Irish Coleoptera: a revised and annotated list. The Irish Naturalists' Journal 25, 1-85.

Anon, 2007. Coillte Social and Environmental Report 2006-07: Coillte Teoranta, the Irish Forestry Board, Dublin, Ireland.

Bathon, H., 1996. Impact of entomopathogenic nematodes on non-target hosts. Biocontrol Science and Technology 6, 421-434.

Becker, G., 1950. Bestimmung von Insektenfraßschäden an Nadelholz. Zeitschirift Fur Angewandte Entomologie-Journal of Applied Entomology 31, 275-303.

Bílý, S., Mehl, O., 1989. Longhorn Beetles (Coleoptera, Cerambycidae) of Fennoscandia and Denmark. Fauna Entomologica Scandinavica 22. Scandinavian Science Press, Copenhagen, Denmark.

Boff, M.I.C., Zoon, F.C., Smits, P.H., 2001. Orientation of Heterorhabditis megidis to insect hosts and plant roots in a Y-tube sand olfactometer. Entomologia Experimentalis et Applicata 98, 329-337.

Brixey, J.M., Moore, R., Milner, A.D., 2006. Effect of entomopathogenic nematode (Steinernema carpocapsae Weiser) application technique on the efficacy and distribution of infection of the large pine weevil (Hylobius abietis L.) in stumps of Sitka spruce (Picea sitchensis Carr.) created at different times. Forest Ecology and Management 226, 161-172.

Brown, I.M., Gaugler, R., 1997. Temperature and humidity influence emergence and survival of entomopathogenic nematodes. Nematologica 43, 363-375.

Dillon, A.B., 2003. Biological control of the large pine weevil, Hylobius abietis L., (Coleoptera: Curculionidae) using entomopathogenic nematodes. $\mathrm{PhD}$ thesis submitted at National University of Ireland Maynooth, Ireland.

Dillon, A.B., Ward, D., Downes, M.J., Griffin, C.T., 2006. Suppression of the large pine weevil Hylobius abietis (L.) (Coleoptera: Curculionidae) in pine stumps by entomopathogenic nematodes with different foraging strategies. Biological Control 38, 217-226.

Dillon, A.B., Downes, M.J., Ward, D., Griffin, C.T., 2007. Optimizing application of entomopathogenic nematodes to manage large pine weevil, Hylobius abietis L. (Coleoptera:Curculionidae) populations developing in pine stumps Pinus sylvestris. Biological Control 40, 253-263.

Dillon, A.B., Rolston, A.N., Meade, C.V., Downes, M.J., Griffin, C.T., 2008. Establishment, persistence, and introgression of entomopathogenic nematodes in a forest ecosystem. Ecological Applications 18, 735-747.

Dillon, A. B., Foster, A., Williams, C. D., Griffin, C. T., 2012. Environmental safety of entomopathogenic nematodes - effects on abundance, diversity and community structure of non-target beetles in a forest ecosystem. Biological Control. Under review.

Dowds, B.C.A., Peters, A., 2002. Virulence mechanisms. In: Gaugler, R. (Ed.), Entomopathogenic Nematology. CABI Publishing, Wallingford, England, pp. 79-99.

Downes, M.J., Griffin, C.T., 1996. Dispersal behavior and transmission strategies of the entomopathogenic nematodes Heterorhabditis and Steinernema. Biocontrol Science and Technology 6, 347-356.

Duffy, E.A.J., 1953. A Monograph of the Immature Stages of British and Imported Timber Beetles (Cerambycidae). British Museum of Natural History, London, England.

Duncan, L.W., Dunn, D.C., Bague, G., Nguyen, K., 2003. Competition between entomopathogenic and free-living bactivorous nematodes in larvae of the weevil Diaprepes abbreviatus. Journal of Nematology 35, 187-193.

Ennis, D.E., Dillon, A.B., Griffin, C.T., 2010. Simulated roots and host feeding enhance infection of subterranean insects by the entomopathogenic nematode Steinernema carpocapsae. Journal of Invertebrate Pathology 103, 140-143.

Evans, H., Moore, R., Heritage, S., Wainhouse, D., 2004. Developments in the integrated management of pine weevil, a pest of restocking in conifer plantations: Forest Research Annual Reports and Accounts 2003-2004. Forestry Comission, England.

Fallon, D.J., Solter, L.F., Keena, M., McManus, M., Cate, J.R., Hanks, L.M., 2004. Susceptibility of Asian longhorned beetle, Anoplophora glabripennis (Motchulsky) (Coleoptera: Cerambycidae) to entomopathogenic nematodes. Biological Control 30, 430-438.

Forst, S., Dowds, B., Boemare, N.I., Stackebrandt, E., 1997. Xenorhabdus and Photorhabdus spp.: bugs that kill bugs. Annual Review of Microbiology 51, 47-72.

Gaugler, R., 1988. Ecological considerations in the biological control of soilinhabiting insects with entomopathogenic nematodes. Agriculture Ecosystems \& Environment 24, 351-360.

Gaugler, R., Lewis, E., Stuart, R.J., 1997. Ecology in the service of biological control: the case of entomopathogenic nematodes. Oecologia 109, 483-489.

Georgis, R., Poinar, G.O., 1983. Effect of soil texture on the distribution and infectivity of Neoaplectana glaseri (Nematoda: Steinernematidae). Journal of Nematology 15, 329-332.

Georgis, R., Koppenhöfer, A.M., Lacey, L.A., Bélair, G., Duncan, L.W., Grewal, P.S., Samish, M., Tan, L., Torr, P., van Tol, R.W.H.M., 2006. Successes and failures in the use of parasitic nematodes for pest control. Biological Control 38, 103-123.

Girling, R.D., Ennis, D., Dillon, A.B., Griffin, C.T., 2010. The lethal and sub-lethal consequences of entomopathogenic nematode infestation and exposure for adult pine weevils, Hylobius abietis (Coleoptera: Curculionidae). Journal of Invertebrate Pathology 104, 195-202.

Grewal, P.S., Lewis, E.E., Gaugler, R., Campbell, J.F., 1994. Host finding behaviour as a predictor of foraging strategy in entomopathogenic nematodes. Parasitology 108, 207-215

Griffin, C.T., Moore, J.F., Downes, M.J., 1991. Occurrence of insect-parasitic nematodes (Steinernematidae, Heterorhabditidae) in the Republic of Ireland. Nematologica 37, 92-100.

Grove, S.I., 2002. Saproxylic insect ecology and the sustainable management of forests. Annual Review of Ecology and Systematics 33, 1-23.

Hedgren, P.O., 2007. Early arriving saproxylic beetles (Coleoptera) and parasitoids (Hymenoptera) in low and high stumps of Norway spruce. Forest Ecology and Management 241, 155-161.

Hilszczanski, J., Gibb, H., Hjältén, J., Atlegrim, O., Johansson, T., Pettersson, R.B., Ball, J.P., Danell, K., 2005. Parasitoids (Hymenoptera, Ichneumonoidea) of saproxylic beetles are affected by forest successional stage and dead wood characteristics in boreal spruce forest. Biological Conservation 126, 456-464.

Hominick, W.M., 2002. Biogeography. In: Gaugler, R. (Ed.), Entomopathogenic Nematology. CABI publishing, Wallingford, England, pp. 115-145.

Jabbour, R., Barbercheck, M.E., 2008. Soil and habitat complexity effects on movement of the entomopathogenic nematode Steinernema carpocapsae in maize. Biological Control 47, 235-243.

Johansson, T., Gibb, H., Hjältén, J., Pettersson, R.B., Hilszczanski, J., Alinvi, O., Ball, J.P., Danell, K., 2007. The effects of substrate manipulations and forest management 
on predators of saproxylic beetles. Forest Ecology and Management 242, 518529.

Jonsell, M., Hansson, J., Wedmo, L., 2007. Diversity of saproxylic beetle species in logging residues in Sweden - comparisons between tree species and diameters. Biological Conservation 138, 89-99.

Kaya, H.K., Gaugler, R., 1993. Entomopathogenic nematodes. Annual Review of Entomology 38, 181-206.

Kaya, H.K., Koppenhöfer, A.M., 1996. Effects of microbial and other antagonistic organisms and competition on entomopathogenic nematodes. Biocontrol Science and Technology 6, 357-372.

Kaya, H.K., Stock, S.P., 1997. Techniques in insect nematology. In: Lacey, L.A. (Ed.) Manual of techniques in insect pathology. Academic Press, New York, pp. 281384.

Kenis, M., Wegensteiner, R., Griffin, C.T., 2004. Parasitoids, predators, nematodes and pathogens associated with bark weevil pests. In: Leutier, F. (Ed.), Bark and wood boring insects in living trees in Europe, a synthesis. Springer, Netherlands, pp. 395-414.

Kruitbos, M.L., Heritage, S., Wilson, M.L., 2009. Phoretic dispersal of entomopathogenic nematodes by Hylobius abietis. Nematology 11, 419-427.

Kruitbos, L.M., Heritage, S., Hapca, S., Wilson, M.J., 2010. The influence of habitat quality on the foraging strategies of the entomopathogenic nematodes Steinernema carpocapsae and Heterorhabditis megidis. Parasitology 137, 303309.

Kuś, J., Kuś, D., 2004. Entomofauna rozkładającego się drewna świerka, buka brzozy na terenie Karkonoskiego Parku Narodowego. Opera Corcontica 41, 269280.

Leather, S.R., Day, K.R., Salisbury, A.N., 1999. The biology and ecology of the large pine weevil, Hylobius abietis (Coleoptera: Curculionidae): a problem of dispersal? Bulletin of Entomological Research 89, 3-16.

Lewis, E.E., Grewal, P.S., Gaugler, R., 1995. Hierarchical order of host cues in parasite foraging strategies. Parasitology 110, 207-213.

Lewis, E.E., Campbell, J., Griffin, C., Kaya, H., Peters, A.J., 2006. Behavioral ecology of entomopathogenic nematodes. Biological Control 38, 66-79.

Långström, B., Day, K.R., 2004. Damage, control and management of weevil pests, especially Hylobius abietis. In: Leutier, F. (Ed.), Bark and Wood Boring Insects in Living Trees in Europe, a Synthesis. Springer, Netherlands, pp. 415-444.

Lindegren, J.E., Yamashita, T.T., Barnett, W.W., 1981. Parasitic nematode may control carpenterworm in fig trees. California Agriculture 35, 25-26.

Markowski, C.A., Markowski, E.P., 1990. Conditions for the effectiveness of a preliminary test of variance. American Statistician 44, 322-326.

Molyneux, A.S., Bedding, R.A., 1984. Influence of soil texture and moisture on the infectivity of Heterorhabditis sp. D1 and Steinernema glaseri for larvae of the sheep blowfly, Lucilia cuprina. Nematologica 30, 358-365.

Neter, J., Kutner, M.H., Nachtsheim, C.J., Wasserman, W., 1996. Applied Linear Statistical Models, fourth ed. Richard D. Irwin Inc., Chicago.

Portillo-Aguilar, C., Villani, M.G., Tauber, M.J., Tauber, C.A., Nyrop, J.P., 1999. Entomopathogenic nematode (Rhabditida: Heterorhabditidae and Steinernematidae) response to soil texture and bulk density. Environmental Entomology 28, 1021-1035.
Pye, A.E., Burman, M., 1977. Pathogenicity of the nematode Neoplectana carpocapsae (Rhabditida, Steinernematidae) and certain microorganisms towards the large pine weevil, Hylobius abietis (Coleoptera, Curculionidae). Annales Entomologici Fennici 43, 115-119.

Pye, A.E., Burman, M., 1978. Neoaplectana carpocapsae: infection and reproduction in large pine weevil larvae, Hylobius abietis. Experimental Parasitology 46, 1-11.

Saunders, J.E., Webster, J.M., 1999. Temperature effects on Heterorhabditis megidis and Steinernema carpocapsae infectivity to Galleria mellonella. Journal of Nematology 31, 299-304.

Shamseldean, M., Abd-Elgawad, M., 1995. Survival and infectivity of entomopathogenic nematodes under environmental stress. Anzeiger Fur Schadlingskunde 68, 31-33.

Shapiro-Ilan, D.I., Gouge, D.H., Piggott, S.I., Fife, J.P., 2006. Application technology and environmental considerations for use of entomopathogenic nematodes in biological control. Biological Control 38, 124-133.

Siitonen, I., 2001. Forest management, coarse woody debris and saproxylic organisms: fennoscandian boreal forests as an example. Ecological Bulletins 49, 11-41.

Skrzecz, I., Majewski, A., 2010. Impact of time of application on the efficacy of entomopathogenic nematodes used against Hylobius abietis. Presentation at the IUFRO conference 'Population dynamics, biological control, and integrated management of forest insects.' Eberswalde, Germany 2010. Abstract: <http:// www.forestinsects.org/iufro/eberswalde/documents/IUFRO_2010_Eberswalde_ Abstracts.pdf> (last accessed February 2012).

Smits, P.H., 1996. Post-application persistence of entomopathogenic nematodes. Biocontrol Science and Technology 6, 379-388.

Solter, L.F., Keena, M., Cate, J.R., McManus, M.L., Hanks, L.M., 2001. Infectivity of four species of nematodes (Rhabditoidea: Steinernematidae, Heterorhabditidae) to the Asian longhorn beetle, Anoplophora glabripennis (Motchulsky) (Coleoptera: Cerambycidae). Biocontrol Science and Technology 11, 547-552.

Speight, M.C.D., 1989. Saproxylic invertebrates and their conservation. Nature and Environment Series. Council of Europe, Strasbourg, France.

Steiner, S., 1999. Rote Liste der Bockkäfer Kärntens. Naturschutz Kärnten 15, 269 286.

Sverdrup-Thygeson, A., Ims, R.A., 2002. The effect of forest clearcutting in Norway on the community of saproxylic beetles on aspen. Biological Conservation 106 , 347-357.

Torr, P., Heritage, S., Wilson, M.J., 2004. Vibrations as a novel signal for host location by parasitic nematodes. International Journal for Parasitology 34, 997-999.

Tozlu G., Göktürk, T., Gültekin, L., 2010. Ormanlarinda Sariçam (Pinus sylvestris L.) Ve Titrek Kavak (Populus tremula L.) Da Zararli Coleoptera Türleri. III. Ulusal Karadeniz Ormancilık Kongresi IV, 1377-1382.

Twinn, P.F.G., Harding, P.T., 1999. Provisional Atlas of the Longhorn Beetles (Coleoptera, Cerambycidae) of Britain. Dorset Press, Dorset, Huntingdon Biological Records Centre.

van Lenteren, J.C., Babendreier, D., Bigler, F., Burgio, G., Hokkanen, H.M.T., Kuske, S. Loomans, A.J.M., Menzler-Hokkanen, I., van Rijn, P.C.I., Thomas, M.B., Tommasini, M.G., Zeng, Q.Q., 2003. Environmental risk assessment of exotic natural enemies used in inundative biological control. BioControl 48, 3-38. 